\title{
1. Introduction to the Handbook on Decentralization, Devolution and the State Ignacio Lago
}

\section{DECENTRALIZATION IN THE TWENTY-FIRST CENTURY}

Matryoshka dolls, more commonly known as Russian or babushka dolls, are a set of wooden figures nested into each other. All around the world, centralized states have progressively been replaced with Matryoshka doll-like governance structures wherein power is shared across multiple levels of organization that directly govern citizens within their jurisdiction.

The concept of decentralization of power encompasses a wide variety of institutional arrangements; not surprisingly, there is no universal, uncontested definition or even consensus on how it should be measured. As Bird (1993: 308) rightly argues, "[fiscal] decentralization seems often to mean whatever the person using the term wants it to mean". A minimal and broad definition employed by empirically oriented scholars and practitioners states that "decentralization entails the transfer of political, fiscal, and administrative powers to subnational units of government” (World Bank, 2000: 108).

Roughly speaking, decentralization covers three dimensions: political, administrative, and fiscal. Political decentralization means that subnational offices sought by political elites are elected by citizens. Power is shared between the national and subnational governments, although the national office is always the most important electoral prize. The more important the subnational office (i.e., the less control national governments exert over local areas), the greater the degree of decentralization.

Administrative decentralization involves the transfer of functions from the national government to local units of government and leaving the national governments the right to interfere directly in local administration. Three varieties of administrative decentralization may be distinguished according to the degree of independent decision-making exercised at the local level (Bird and Vaillancourt, 2008: 3):

- Deconcentration means the dispersion of responsibilities within a central government or regional branch offices of local administrative units.

- Delegation refers to situations in which local governments act as agent for the central government, executing functions on its behalf.

- Devolution captures situations in which both the implementation and the authority to decide what is done is in the hands of local governments.

Fiscal decentralization refers to the transfer of responsibility for expenditure and revenues to subnational levels of government. In order to make decentralization work, subnational governments "must have an adequate level of revenues either raised locally or transferred from the national government - as well as the authority to make decisions about expenditure" (Rondinelli, 1999: 3). 


\section{Handbook on decentralization, devolution and the state}

Together with the spread of democracy, the most defining feature of governance since the Second World War is the worldwide trend towards decentralization. Decentralization in the last few decades has been defined by three temporal, political, and geographical characteristics. First, decentralization of governance is increasingly becoming a dominant trend worldwide. Figure 1.1 shows the average annual degree of decentralization from 1950 to 2010; data are drawn from the Regional Authority Index (RAI) (Hooghe et al., 2016; Shair-Rosenfield et al., 2021). ${ }^{1}$ The number of countries included in the sample increased over time (from 48 in 1950-1954 to 81 in 2008-2010). The left side of Figure 1.1 includes all countries; the right side is focused on the 48 countries included in all years. Two features are particularly interesting. On the one hand, countries are much more decentralized in the twenty-first century than immediately after the Second World War. On the other hand, the trend of decentralization has been unstoppable since the 1970s. When the World Bank (2000: 124) concludes that "strategies to stop decentralization are unlikely to succeed, as the pressures to decentralize are beyond government control," it is far from exaggerating.

A relevant question that emerges from Figure 1.1 is whether the decentralization trend has affected the gap between the most- and the least-decentralized countries. Figure 1.2 addresses the question. Using again the RAI, the degree of decentralization in 48 countries in 1950 and

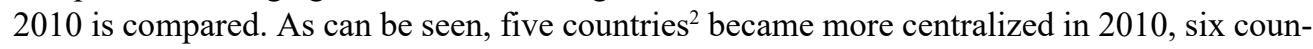
tries underwent no change, and 37 countries became more decentralized between 1950 and
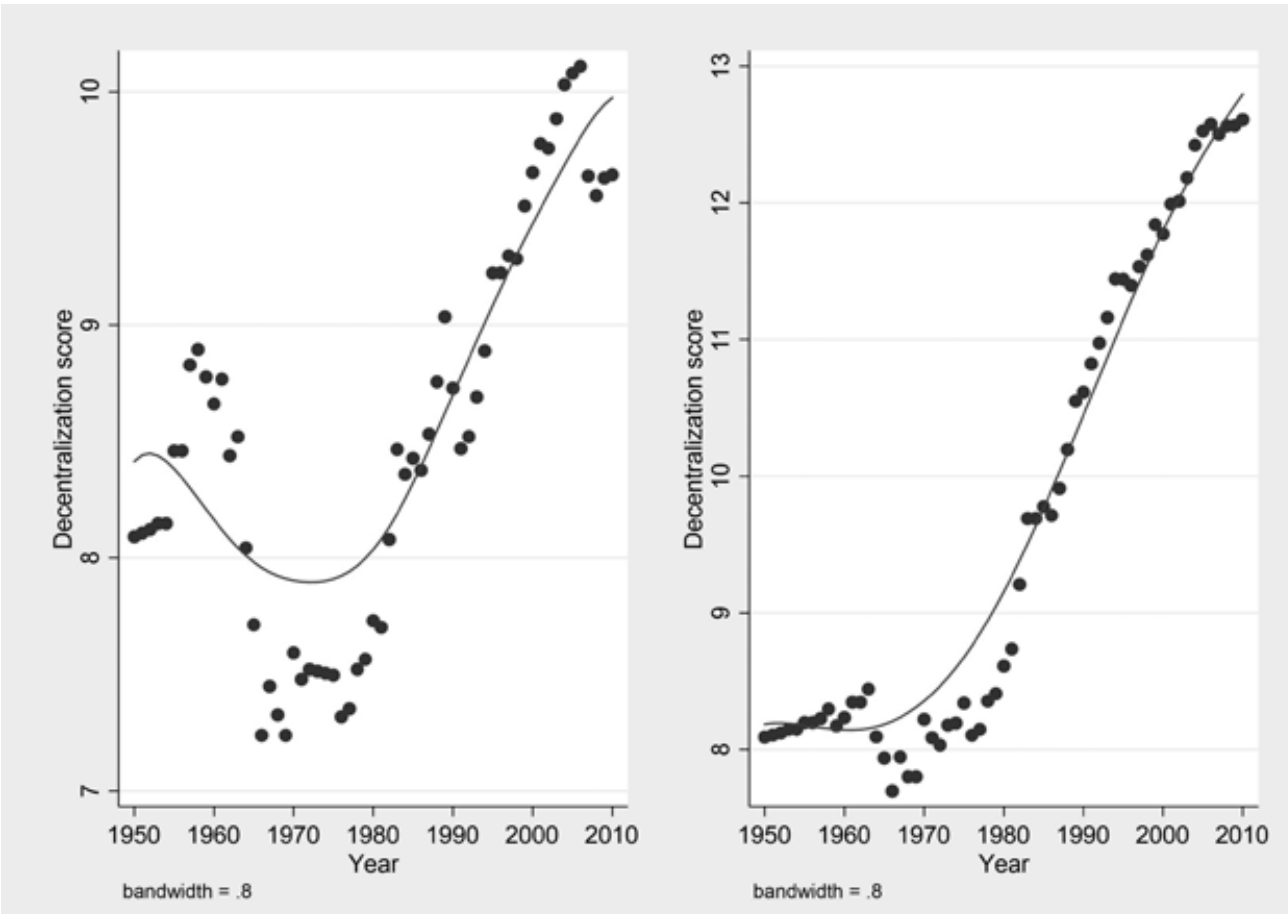

Source: Regional Authority Index.

Figure 1.1 Decentralization in the world from 1950 to 2010 


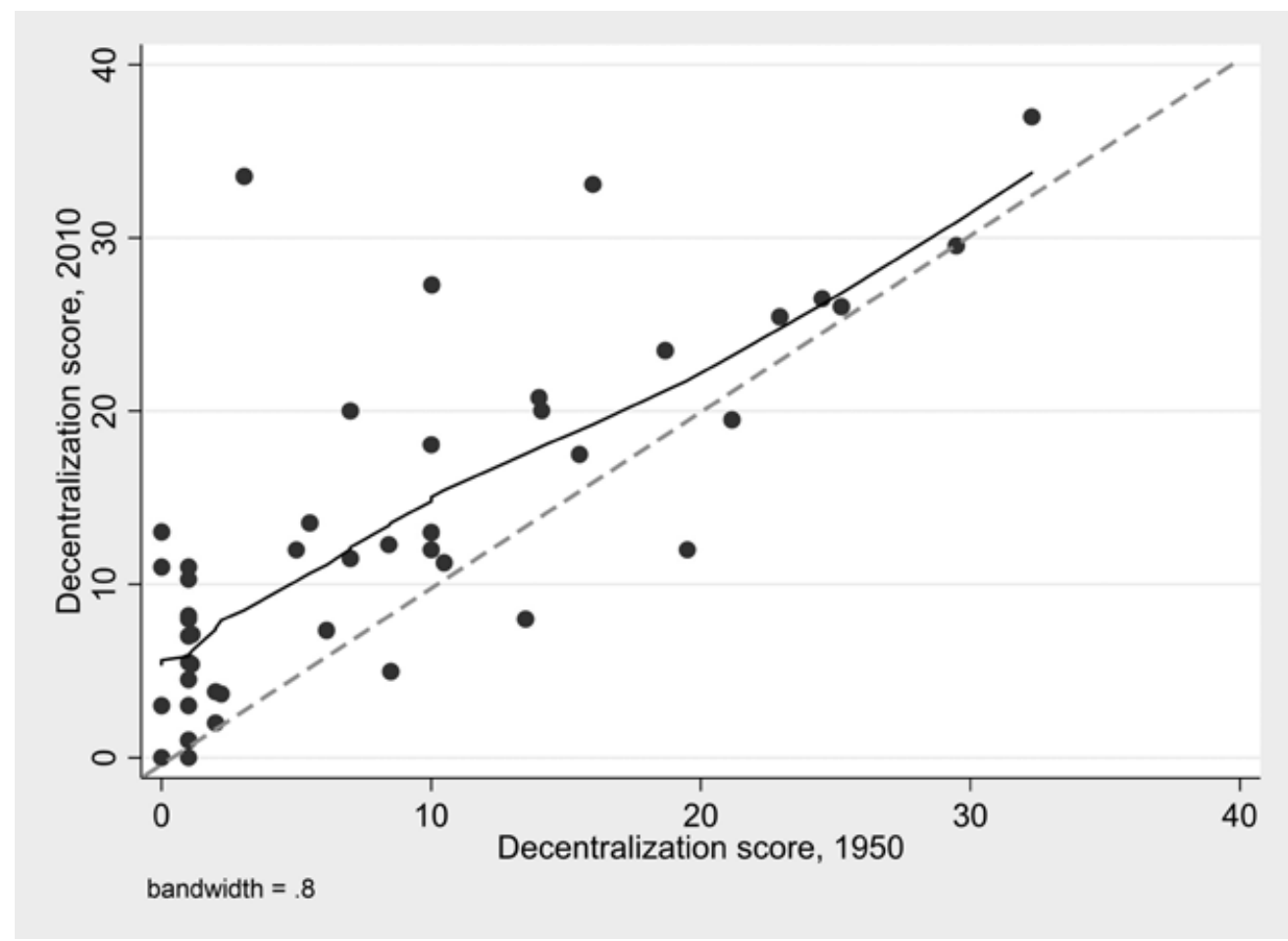

Source: Regional Authority Index.

Figure 1.2 Decentralization in 48 countries in 1950 and 2010

2010. Interestingly, the relationship is largely linear: decentralization has not yet stopped, even in the most decentralized countries. However, as the lowest curve is slightly above the linear prediction, particularly when the degree of decentralization was low in 1950, it can be inferred that the gap between the most and the least decentralization countries is reduced. In 1950, the coefficient of variation was 109.07; in 2010 it was 78.63. From a qualitative perspective, in those countries where decentralization reforms have occurred, they have generally been in the direction of greater regional authority (Hooghe et al., 2010: 53).

Second, although at first glance it may be surprising, decentralization is also compatible with non-democracies. Both in democracies and non-democracies, decisions affecting people's lives have increasingly been made at the subnational level. A box plot summarizing the degree of decentralization in democracies and non-democracies is shown in Figure 1.3. Following Boix et al. (2018), a country is defined as democratic if it meets the following conditions for both contestation and participation: (1) the executive is directly or indirectly elected in popular elections and is responsible either directly to voters or to a legislature; (2) the legislature (or the executive if elected directly) is chosen in free and fair elections; and (3) a majority of adult men has the right to vote. Two different measures of decentralization are employed. On the one hand, there is the RAI (published in 2018). I used this year instead of 2010 because 14 more countries were included (resulting in 95 countries: 19 non-democracies and 76 democracies). In order to increase the number of countries, I also used the Aggregate Decentralization Index 


\section{Handbook on decentralization, devolution and the state}

(di) by Ivanyna and Shah (2014), as it is available for 182 countries (78 non-democracies and 104 democracies) in 2005. The index displays government decision-making at the local level rather than at the subnational levels. The Index (di) incorporates local government expenditure in consolidated general government expenditures for all orders of government, the security of existence of local governments (measured with the constitutional and legal restraints on arbitrary dismissal of local governments) and fiscal, political, and administrative indexes. The higher the value, the more decentralized the country is at the local level.

Figure 1.3 shows that non-democracies, on average, are significantly decentralized. When focusing on decentralization at the regional level (left side), the RAI averages are remarkably similar in democracies (10.84) and non-democracies (9.78). The difference is not statistically significant. When examining decentralization at the local level (right side), democracies (3.0) are more decentralized than non-democracies (0.89); this difference is statistically significant at the 0.01 per cent level.

Third, decentralization is a worldwide phenomenon that is not limited to large or wealthy countries. Using again data from the Regional Authority Index in 2018 for 95 countries in different regions, ${ }^{3}$ Figure 1.4 shows geographical differences in the degree of decentralization. The data show that the six regions are substantially decentralized; the median extends from 26.26 in Northern America to 6.41 in Latin American and the Caribbean. However, not

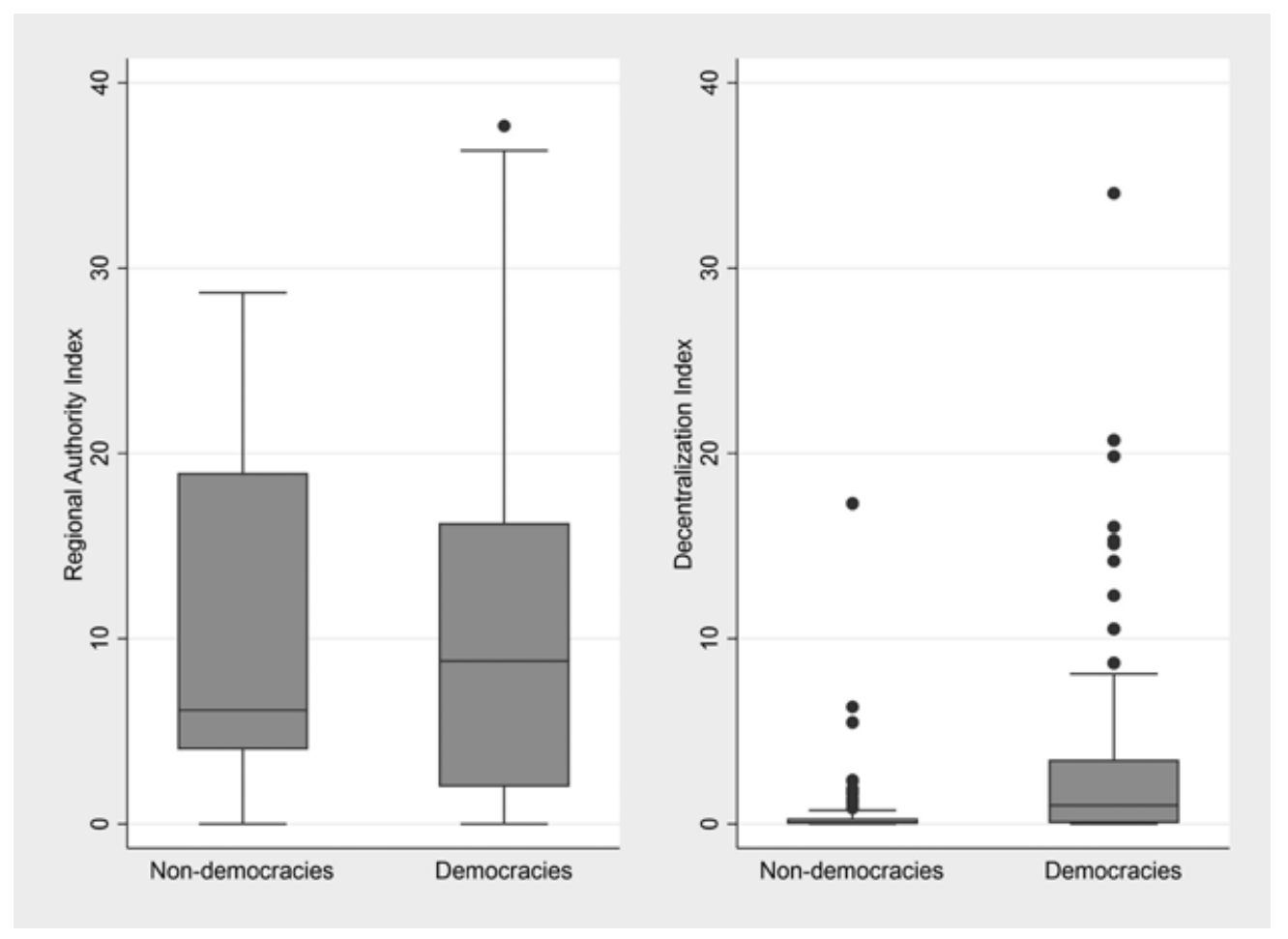

Source: $\quad$ Regional Authority Index 2018; Aggregate Decentralization Index (Ivanyna and Shah, 2014).

Figure 1.3 Decentralization in democracies and non-democracies 
surprisingly, regions with the largest and wealthiest countries and the most traditional democracies tend to be the most decentralized.

This widespread adoption of decentralizing reforms is puzzling at first glance (O’Neill, 2003). As the powers of central governments are diminished, why do they choose the transfer of political and economic power to subnational authorities? Some explanations account for the rationale of decentralization. For instance, O’Neill (2003) argues that decentralization represents a desirable strategy for parties whose support at subnational levels appears more secure than their prospects in national elections. More specifically, when political parties predict that they will be unable to control central power in a centralized governing structure - and further, that they could win a substantial proportion of sub-national offices if contested democratically - decentralization becomes more attractive. Similarly, for Meguid (2009), decentralization is a means to bolster a governing party's national-level electoral strength. It is a tool, akin to policy appeasement, used to co-opt pro-decentralization regionalist party voters.

While certainly valuable, this perspective on decentralization does not explain why decentralizing reforms have also taken place in non-democracies. As dictators are not electorally accountable, the benefits of decentralization should go over the electoral arena. A limited amount of research has investigated decentralization in non-democracies. On one hand, it has been argued that the rationale of decentralization in non-democracies is different from that in democracies. In the former, political decentralization is a way to co-opt elites (Reuter et al.,

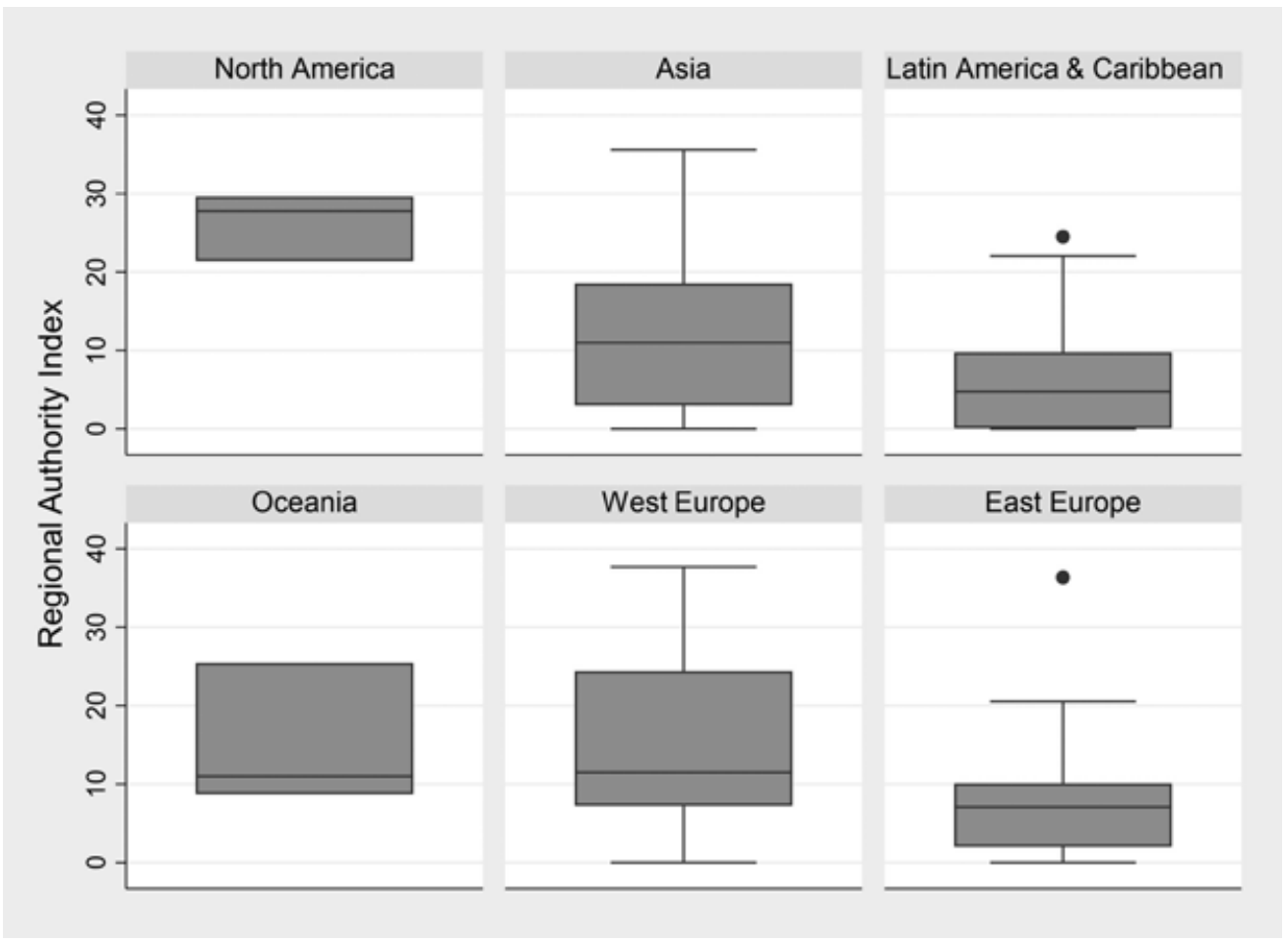

Source: Regional Authority Index 2018.

Figure 1.4 Geographical differences in decentralization in 2018 
2016). On the other hand, the conventional argument explaining decentralizing reforms and travelling across political regimes has to do with the positive effect of decentralization on macroeconomic performance and growth (see Amagoh and Amin, 2012). For instance, the classical argument by Oates (1977) claims that the positive effect of fiscal decentralization on economic growth has to do with the "diversification hypothesis," that is, uniform levels of public goods and services across jurisdictions will generally be inefficient.

\section{STRUCTURE OF THE HANDBOOK}

The Handbook on Decentralization, Devolution and the State offers a critical examination of existing research in the field of decentralization of power in contemporary political regimes through the collection of a set of chapters written by 30 scholars. As decentralization of governance is increasingly becoming a dominant trend worldwide, the goals of this volume are (a) to provide the state of the art of the scholarship on decentralization using original data analyses; (b) to lay out the ongoing discussions and research gaps, and (c) to uncover potential venues for future research. The approach is multidisciplinary. The Handbook has assembled a team of internationally renowned scholars in political science, economics, sociology, and geography; this group provides a comprehensive and comparative overview of decentralization through a plurality of approaches.

The Handbook is divided into four sections and eighteen chapters. In the first part, the main conceptual and empirical approaches are discussed and the current research agenda on decentralization is presented. We focus our attention on the different concepts and measures of decentralization and, further, presentation of the main research questions addressed when examining decentralization as a dependent and independent variable. In the second part, we show how the degree and type of decentralization varies over time and across countries, with a particular emphasis on the most decentralized regions in the world, namely Asia, Western Europe, Latin America, and North America. The third section examines how political decentralization affects the behaviour of parties and voters in national and subnational elections. More specifically, the influential second-order election model, accounting for multi-level electoral politics, is revisited. The section is particularly interested in four dependent variables: the attribution of political responsibilities, the extent to which the voters attribute blame or credit for economic outcomes, national unity and national and regional identities, and turnout. Finally, the social and economic consequences of decentralizing power are the focus of the fourth section. Special attention is given to how decentralization affects income inequality, economic development, social services, and the quality of governance. Focus is also placed on the impact of both the Great Recession of 2008 and the COVID-19 pandemic on intergovernmental relations.

\section{NOTES}

1. The Regional Authority Index (RAI) is a measure of the authority of regional governments across ten dimensions: institutional depth, policy scope, fiscal autonomy, borrowing autonomy, representation, law making, executive control, fiscal control, borrowing control, and constitutional reform. These ten dimensions constitute two domains of authority: self-rule, or the authority a regional government exerts within its territory; and shared rule, or the authority a regional government or its 
representatives exerts in the country as a whole. Country scores aggregate scores for each regional tier and individual regional governments in a country.

2. The five countries are Brazil, Costa Rica, Cuba, Ecuador, and Sweden.

3. Unfortunately, no African countries are included in the sample.

\section{REFERENCES}

Amagoh, F. and Amin, A.A. (2012) An examination of the impacts of fiscal decentralization on economic growth. International Journal of Business Administration, 3 (6), 72-81.

Bird, R.M. (1993) Threading the fiscal labyrinth: Some issues in fiscal decentralization. National Tax Journal, 46 (2), 207-227.

Bird, R.M. and Vaillancourt, F. (2008) Fiscal Decentralization in Developing Countries. Cambridge: Cambridge University Press.

Boix, C., Miller, M., and Rosato, S. (2018) Boix-Miller-Rosato Dichotomous Coding of Democracy, 1800-2015. https://dataverse.harvard.edu/dataset.xhtml?persistentId=doi:10.7910/DVN/FJLMKT.

Hooghe, L., Marks, G., and Schakel, A.H. (2010) The Rise of Regional Authority: A Comparative Study of 42 Democracies. London: Routledge.

Hooghe, L., Marks, G., Schakel, A.H., Chapman-Osterkatz, S., Niedzwiecki, S., and Shair-Rosenfield, S. (2016) Measuring Regional Authority: A Postfunctionalist Theory of Governance, Volume I. Oxford: Oxford University Press.

Ivanyna, M. and Shah, S. (2014) How close is your government to its people? Worldwide indicators on localization and decentralization. Economics: The Open-Access, Open-Assessment E-Journal, 8, $1-61$

Meguid, B.M. (2009) Institutional change as strategy: The role of decentralization in party competition. Paper presented at the annual meeting of the Midwest Political Science Association, 67th Annual National Conference, Chicago, IL.

Oates, W.E. (1977) An economist's perspective of fiscal decentralization. In W.E. Gates (ed.), The Political Economy of Fiscal Federalism. Toronto: Lexington Books.

O’Neill, K. (2003) Decentralization as an electoral strategy. Comparative Political Studies, 36 (9), $1068-1091$.

Reuter, O.J., Buckley, N., Shubenkova, A., and Garifullina, G. (2016) Local elections in authoritarian regimes: An elite-based theory with evidence from Russian mayoral elections. Comparative Political Studies, 49 (5), 662-697.

Rondinelli, D. (1999) What is decentralization? In J. Litvack and J. Seddon (eds.), Decentralization Briefing Notes. Washington, DC: World Bank Institute.

Shair-Rosenfield, S., Schakel, A.J., Niedzwiecki, S., Marks, G., Hooghe, L., and Chapman-Osterkatz. S. (2021) Language difference and regional authority. Regional and Federal Studies, 31 (1), 73-97.

World Bank (2000) Entering the 21st Century: World Development Report 1999/2000. Washington, DC: World Bank. 